\section{SPONTANEOUS APPEARANCE OF EXOTIC FORAGE PLANTS IN FRANCE AFTER THE LATE WAR}

$\mathrm{N}$ a communication lately made to the Paris Academy, M. Vibraye states the fact of certain exotic forage plants having appeared in considerable numbers in the central parts of France, after the stay of the army in these localities. He gives the following account of these plants :

"Their appearance, no doubt, results from forage supplied from abroad, the seeds of which had fallen into the ground. At the present time several Mediterranean plants, (chiefly Algerian), having braved the cold of an exceptionally severe winter, are being largely propagated, forming extensive meadows, and changing soil that was formerly arid, and produced no vegetation of importance, to veritable oases. This may probably lead to the definitive introduction of a large number of plants into a more northern region than that which they appear naturally to occupy and to prefer.

"The first notion of the possibility of such plants being brought into French soil, through the fodder consumption of the army, arose in 1870 . A botanist of Strasburg, $M$. Buchinger, wrote to $M$. Franchet (conservator of $m y$ collections) some days before the investment of the place that, on examining the fodder which was being given to the horses, he had found in it forty-four species of plants beionging to the Mediterranean region, and most of which were Algerian. He suggested to M. Franchet to make observations, and see whether some of these plants would not appear in the soil. The prediction was verified; and in April 187I, M. Franchet found two exotic centauries, and communicated the fact to $M$. Nouel, the director of the Orleans Museum. Since then these two botanists have made minute researches on the subject, and have discovered many more such plants. This is, briefly, the history of the discovery. The places where the phenomenon has been best observed are in the Department of the Loire-et-Cher: (i) on the right bank of the Loire, near the railway ; (2) on the left bank, the country about Blois. Then, too, in the Communes of Cour, and more especially of Cheverny, which districts were successively occupied. Observations have also been made at Orleans, on the Boulevard Saint Jean, and the Isle of Arrault.

"I shall best recount these observations by giving them as they were written down in the order of date.

"On the 18th March, I872, certain new plants, observed the previous year at Blois and Orleans, had increased considerably on arid soil, which formerly bore only some poor and stunted herbs. Each of the districts furnished about 90 to roo species. But the species were not the same in each district, and the total number of species met with, was 157 , belonging to twenty-one families, as follows :-

\begin{tabular}{|c|c|c|c|c|c|}
\hline Ranunculace & & 3 & & Compositæ & . 28 \\
\hline Resedaceæ & . & I & & Convolvulace & I \\
\hline Cruciferæe. & & 8 & & Borraginea & . \\
\hline Silener & 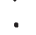 & 5 & & Verbasceæ & \\
\hline Alsinex & . & - $\quad \mathbf{I}$ & & Plantagineæ & \\
\hline Lineæ. . & . & . $\mathbf{I}$ & & Labiatæ & \\
\hline Malvaceæ. & . & . & & Amaranthace & \\
\hline Geraniaceæ & - & . 7 & & Salsolacea & \\
\hline Leguminose & . & . $5^{2}$ & 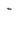 & Polygoneæ & \\
\hline Umbelliferæe & & . 4 & & Graminea & \\
\hline
\end{tabular}

$$
\text { Entire total . . } 157
$$

"The first observations could not be considered quite definitive, and there were some species which it was, perhaps, a little premature to determine; but after deductions made on this account there remained I4O species; a number much larger than that of the plants on the best meadow lands in France, which, according to botanists, do not furnish more than 90 to 100 species.

"It will be seen that the Leguninosæ ( 52 species) form about one-third of the whole, while the Graminex and the Compositæ form each about one-fifth (28 species). Among the Leguminosæ trefoil and lucerne predominated; I 2 kinds of trifolium were counted, and Io or 11 of medicago ; the 28 Compositæ belonged to 2 I genera, and the 28 Graminex to 16 different genera. Two thirds of these forage plants are annuals or biennials.

"On the 12th April a fresh examination of the Blois district showed that many of the species, and especially the medicagos, had not only persisted but been propagated from seeds. Unfortunately for the full development of this, the land was used as a pasturage for sheep, which devoured the plants in proportion to their growth, and uprooted many with their feet, the arid soil having little cohesion. At Cheverny, where I had enclosed certain spaces, several Algerian plants attained a superb growth; among these, trefoil, melilot, phalaris, and alopecurus.

"By the 19th April it was evident that not only a large number of species had persisted, but that from being rare and poor the previous year, they had developed to a wonderful extent, notably the Alopecurus utriculatus, Vulpia ligustica, Avena barbata, Trifolium nigrescens, Trifolizm isthocarpum, all southern and forage plants. The Medicagos spharocarpa and pentacycla reappeared in great abundance where they had escaped the cattle, or the sickles of women in search of herbs. It was difficult to persuade these herb-gatherers to a temporary self-sacrifice with the view of ultimate advantage in respect of forage.

"On the 27th April my attention was called to the large number of annuals and biennials disseminated. The annual plants, which De Candolle called monocarpian, because they terminated their existence by a perfect and unique fructification, are invariably reproduced by the dissemination of their seeds when they have come to maturity; the individual dies, while the species becomes perennial; which duration, on the other hand, is temporarily acquired by the individual, when a scythe, or the grazing of cattle, retards the last and indispensable phase of the plant's existence.

"At this date, April 27, trefoil and lucerne promised to be very abundant in the Blois district. By the Ist of May an incessant appearance of new species was noticed; and it seemed beyond a doubt that before the end of the season the four localities of Blois, Cheverny, Vendôme, and Orleans, would furnish not fewer than 200 species, of which I 70 at least were peculiar to meadows and pasture lands.

"On the 3rd May a new fact presented itself. During the war a forage depôt had stood at the side of the market place of Cour Cheverny, but last year no appearance of any new plant had been discovered there, notwithstanding careful search. On the 3 rd some twelve species of foreign forage plants made their appearance, and others were expected. This shows that the seeds had remained in the soil for sixteen months without alteration of their germinating properties. This is an interesting fact, and a corollary of a law of rotation observed in all natural meadows, viz., the temporary, disappearance of dominant species, yielding for an indeterminate period to new types, which they by-and-by come to displace, when they meet with certain favouring atmospheric influences, not very fully understood.

"The Algerian plants withstood successfully the frost of the I2th May, which did much damage to our vines and the shoots of certain trees, especially indigenous conifers."

M. Vibraye, in closing his note, speaks of the above phenomena as being quite an event. It is not the ephemeral appearance of a few plants sparsely disseminated, raising the problematical hope of fixing in the soil a useful vegetable --it is an exodus; the migration, not of a modest florule, but of a flora, independent and complete. It is, in a word, a treasure which the central districts of France are called on to study and to appropriate. He argues that the propagation of these plants should not be left to chance, but that human skill should be brought to bear on it. 